\title{
Iisus Hristos, Omul asumat în Dumnezeu, în teologia lui Hans Urs Balthasar
}

\section{Robert Iulian PĂUN}

Abstract: The embodiment of God's Word, represents for the whole theological vision of Hans Urs Balthasar, the main point and even more than that, the key of any theology. For the Swiss theologian, the human nature assuming by the divine hypostasis represents the only new thing appeared after the act of the world creation, therefore, opposed to other theologians he emphasizes even substantiates his theology on this historical and rescue act The Logos embodiment is an extremely complex phenomenon, rooted in the being above all beings, the Holy Trinity. We can see within the Balthasar exposal, an association and similarity with the fourteenth century faith confessions of Saint Philotheos Kokkinos and Saint Gregory Palamas. So here's a first attempt for the Catholic theology of approaching the top of Orthodox dogmatic teaching.

Keywords: Humanity, mission, man, genuine, hypostasis, kenosis, picture, Trinity, perichoresis, immanent, will, obedience, love. 


\section{Robert Iulian PĂUN}

\section{Introducere}

În acest referat doresc să fac un pas decisiv spre a înţelege hristologia trinitară a lui Hans Urs Balthasar, aşa cum el a subliniat-o mai ales prin eseurile teologice Verbum Caro, Gloria, trecând prin Teodramatica, până la lucrarea Teologica.

„Nu există o altă intrare în misterul trinitar în afara revelaţiei Sale în Iisus Hristos şi în Sfântul Duh, şi nici o afirmare asupra Treimii imanente dacă nu se vrea să se cadă în golul propoziţiilor abstracte şi de nici o importanţă istorico-mântuitoare"1. Într-adevăr spune Balthasar cu multă vigoare, în sintonie cu toată opera sa hristologică „,raportul lui Iisus spre Tatăl şi spre Duhul nu este deloc exprimarea şi auto-manifestarea purei Sale umanităţi, ci prin umanitate, este exprimarea Persoanei Sale care este nedespărţită de ea şi care pentru ea se manifestă.

\section{Întruparea Cuvântului, punctul de plecare în teologia creștină}

Deja în 1953, întrebându-se despre datoria și ținta teologiei, Balthasar a exprimat în mod clar că aceasta este și va fi întruparea Cuvântului lui Dumnezeu. Rezultă că „toate problemele Scripturii trebuie să fie înfruntate începând de la hristologie, de la evenimentul lui Verbum Caro. „Sursa primară” a teologiei creştine este întruparea Cuvântului, care este „,imagine”, „exprimare” şi „exegeză a lui Dumnezeu"'.

„Teologica începe cu auto-revelaţia lui Dumnezeu Treimic în întruparea Logosului divin şi Logosul este Cuvânt, Fiu, Interpret al

\footnotetext{
${ }^{1}$ Hans Urs von Balthasar, Verita di Dio, Teologica, volumul 2, Milano, Editura Jaca Book SpA, 1990, p. 109.

${ }^{2}$ Hans Urs von Balthasar, Verbum caro, Sezione quinta. Saggi Teologici 1. Traducere de Giulio Colombi, Milano, Editura Morcelliana-Jaca Book, 2005, p. 159 .
} 
Tatălui. Astfel El se referă la Sine şi aşa vrea să fie indicat. Dar cine ar putea să-L înţeleagă ca ceea ce este, dacă nu ar fi Duhul care ne introduce în adevărul Său şi aşa în raportul Său cu Tatăl? Pe de o parte, Logosul ne promite Duhul ca interpret al Său pentru timpul întoarcerii Sale la Tatăl; dar, pe de o altă parte, tot ceea ce a făcut şi a suferit înainte, de venirea Sa în carne, în patima şi în învierea Sa, El a împlinit deja în Duh, pe care Tatăl 1-a trimis Lui fără măsură”3.

Am individualizat aici deja punctul absolut de plecare a teologie creştine în perspectiva trinitară şi hristologică. Acest punct inedit al creştinismului indică şi unicitatea şi este despărţitura faţă de toate celelalte religii ale lumii. Într-adevăr, propoziţia „Dumnezeu s-a făcut om” este fără îndoială inima mărturiei creştine şi ,,pentru oricare altă religie, din tăcerea altor ,ideologii”, aceasta este o afirmaţie care nu poate fi susţinută, contradictorie în mod fundamental. De aceea aceasta izolează creştinismul de toate celelalte concepţii ale lumii şi mărturii religioase". Creştinismul, însă, în centrul mărturiei sale de credinţă şi de istorie a lumii, pune afirmaţia Evanghelistului Ioan, „Cuvântul S-a făcut trup". Această afirmaţie constituie intrarea în sanctuarul misterului lui Dumnezeu Trinitar. Acest fapt este ,inadmisibil pentru păgâni, pentru evrei cât şi pentru musulmani. Pentru ei, nici cuvântul (profetic) nu este Dumnezeu însuşi, nici Dumnezeu nu poate să devină ceea ce nu era. Pentru creştin, însă, este afirmat cu energie: Cuvântul a fost „la Dumnezeu” şi El însuşi era „Dumnezeu”, şi a „devenit” ceva, şi mai exact nu doar un simplu ,om” (ceea ce este cu siguranţă subînțeles, pentru că „,carne” în Vechiul Testament vrea să indice omul concret, temporan şi caduc, chiar dacă caro, sarx, pune în centru fragilitatea, caducitatea şi mai ales mortalitatea omului). Faptul că în această afirmație stă în centru corpul, caro cardo salutis (carnea este calea spre mântuire), constituie nucleul central de adevăr al „hristologiei lui Logos-sarx”, al creștinismului primitiv, care după

\footnotetext{
${ }^{3}$ Hans Urs von Balthasar, Verita di Dio, Teologica, volumul 2, SpA Milano, Editura Jaca Book, 1990, p. 1.
} 
doctrina greşită a lui Apollinare, într-o clipă secundară, a trebuit să fie completată şi corectată. Este însă şi afirmaţia centrală a întregii teologii anti-gnostică, care rămâne mereu actuală împotriva tuturor maniilor de spiritualizare al evenimentului lui Hristos, ce răsar în mod continuu 4 .

Începând reflecţia asupra faptului că, Cuvântul lui Dumnezeu s-a făcut carne, Autorul în acord cu toată producţia sa precedentă, afirmă: „,Religia creştină este singura care trecând peste faptul cel mai evident, mortalitatea cărnii, ceea ce le-a împins pe toate celelalte religii spre spiritualizare ca pe singurul drum de mântuire, a găsit sfârşitul drumurilor lui Dumnezeu care nu poate fi depăşit ,în carne, în carnea muritoare, euharistică, mistică şi care are putere să renască. Acest om concret Iisus Hristos, este ţinta lui Dumnezeu. Cu el, vrea să devină acelaşi lucru, adică în adevărat „aceiaşi carne" ". Din acest motiv „faptul” întrupării Cuvântului „rămâne punctul de plecare, punctul central al oricărei credinţe creştine şi este înconjurat dogmatic de afirmaţiile protective a marilor Sinoade Ecumenice. Întreaga teologie stă sau cade cu acceptarea credinței în singurul fapt nominat. Oricine îl refuză sau face nişte tăieturi decisive (ca de exemplu cele „anticriste” în scrisorile lui Ioan, erezii care s-au ramificat după primele Sinoade Ecumenice), nu poate genera nici o teologie cu adevărat creştină”.

„Dacă Hristos a fost doar cel mai înalt exemplar al omului natural, dacă creştinismul ar fi fost doar forma cea mai sublimă de religie umană, nu ar mai avea sens astăzi să fim creştini”. Faţă de toate religiile umane şi de tentativele filozofice, care vin de la om, ,de jos”, creştinismul chiar dacă este tot mai ,,singuratic” tocmai pentru că este unicul care asigură mişcarea lui Dumnezeu „de sus”, mărturiseşte faptul că Dumnezeu S-a făcut om prin Iisus Hristos, pentru a dezvălui

${ }^{4}$ Hans Urs von Balthasar, La mia opera ed Epilogo, Einsiedeln, Editura Johannes Verlag, 1987, p. 77.

${ }^{5}$ Hans Urs von Balthasar, Verita di Dio, Teologica, volumul 2, SpA Milano, Editura Jaca Book, 1990, p. 191.

${ }^{6}$ Ibidem, p. 245. 
pe Dumnezeu cel veşnic şi invizibil în „vizibilitatea” cărnii, adică în umanitatea concretă, în istoria trăită.

\section{Posibilitatea Întrupării Cuvântului în Sfânta Treime}

Faptul că Infinitul S-a făcut finit, că Veşnicia a intrat în timp, că Dragostea subzistentă a trecut la opusul său alegând contingenţa condiției umane, luând în sine păcatul, abandonarea şi moartea, toate aceste lucruri constituie novum absolut al întrupării Cuvântului, „paradox" pentru mistica necreştină şi pentru filozofie. Prin urmare posibilitatea ultimă al acestui factum al ,devenirii” lui Dumnezeu trebuie să fie căutat nu în gnoză şi nici în filozofie (Hegel), ci în Dumnezeu Însuşi: în „geneza trinitară”, deci în decizia trinitară în puterea auto-dedicării generative al Tatălui Fiului şi a amândurora Duhului. Balthasar caută şi reflectă despre această posibilitate pe trei nivele: pe planul deschiderii fiinţei (il bonum diffusivum sui), pe planul antropologic (omul ca ,imagine” a lui Dumnezeu), pentru a ajunge la planul teologic, trinitar. Acum, pentru ca întruparea lui Dumnezeu (în sens creştin) să fie posibilă, „,era necesar ca Dumnezeu să poată să treacă de partea noastră fără să abandoneze ,propria” Sa parte. Dar această opoziţie presupune în mod esenţial opoziţia veşnică" a vieţii divine, sprijinită de dragoste, adică ,o donare, un schimb, o comuniune care nu prejudecă identitatea Absolutului, mai mult face din el Binele absolut".

Lumea creată, cu libertatea sa, ,se pune în planul ultim dintre Dumnezeu Tatăl şi Dumnezeu Fiul şi participă la aceea supremă libertate care, în creştinism se identifică cu Duhul divin, pe care Tatăl şi Fiul Îl au în comun, care de la Ei merge manifestând unitatea în dragoste. Deoarece în Duh opoziţia intra-divină este depăşită, iar (în credinţă) devine transparentă ca introducere la viaţa creştină, este posibil să înţelegem, în Duhul lui Dumnezeu (prin credinţă), că 
opoziţia Dumnezeu-om (care pentru raţiune constituie ceva scandalos) este introducerea unei auto-donări libere a lui Dumnezeu lumii”.

\section{Întruparea Mântuitorului: act trinitar si de revelație trinitară}

Punctul de plecare al teologiei creștine (punctul Alfa, constituit din întruparea Cuvântului), este în mod direct legat cu punctul Omega al aceleiași credințe creștine: Sfânta Treime. Aceasta într-un dublu sens: 1) întruparea este un act propriu trinitar; 2) este deasemenea revelarea Persoanelor Treimice. Sunt numeroase pasajele balthasariene care reflectă acest dinamism trinitar al întrupării. Mai înainte de oricare altă considerație va fi utilă o scurtă precizare terminologică. Care este subiectul logic al cristologiei lui Balthasar? Întrebarea nu este nesemnificativă. O confruntare strânsă cu prietenul său contemporan, Karl Barth, poate sa faciliteza o asemenea clarificare. Cristocentrismul lui Barth, cum este deja știut nu începe cu întruparea Cuvântului, ci cu preexistența Sa. Întruparea, ca și „Cuvânt al lui Dumnezeu”, este văzută prezentă și operantă în toată istoria mântuirii, de aceea revelaţia divină este transcendentă istoriei. Locaţia întrupării nu este viaţa lui Iisus, ci moartea Sa. Iisus este Fiul lui Dumnezeu doar odată cu Învierea. În acest sens întruparea nu vine înțeleasă ca un ,,eveniment”, riscându-se astfel volatilizarea asumării naturii umane de către Logos. În acel important document din tranziția barthiană (anii 19221932), intitulat Doctrina Cuvântului lui Dumnezeu. Proologumeni în Dogmatica creștină (1927), teologul de la Basel, așează Cuvântul lui Dumnezeu ca obiect al dogmaticii. În această alegere el vine în mod conștient contra lui Schleiermacher si teologiei oficiale protestante din acel timp, care indica în schimb în doctrina despre credință același obiect al dogmaticii creștine. „Cuvântul lui Dumnezeu (Deus dixit), nu este altul decât Dumnezeu Însuși în revelație. Același Cuvânt al 
lui Dumnezeu vine analizat de Karl Barth in cele trei forme originale ale sale: forma revelată ca și act dinamic al revelației Treimei, forma scrisă în Scripturi (profeți si apostoli) și forma predicată de către Biserică. Realitatea Cuvântului lui Dumnezeu în cele trei forme găsește numai în ea însăși o fundamentare. În consecință, conștiința omului aduce doar o recunoștință. Acesta nu poate deveni real și nu se poate face înțeles decât în virtutea acțiunii Cuvântului Însuși al lui Dumnezeu”. Adevăratul „novissimum” este viața treimică a lui Dumnezeu revelată în Iisus Hristos; manifestarea profundă a Treimii este adevăratul si incomprehensibilul „eschaton” al istoriei mântuirii ${ }^{8}$. Se poate spune că revelația actualizată în Iisus Hristos, este una trinitară - Iisus nu vorbește despre Dumnezeu în general ci îl prezintă pe Tatăl și dăruiește pe Sfântul Duh - iar noi trebuie să ne facem o imagine în jurul existenței și esenței lui Dumnezeu din acest raport trinitar a lui Iisus cu Dumnezeu. Acest raport se manifestă în istoria devenirii lui Iisus ca o eternă devenire" ". Pentru Balthasar urmând atât textul Evangheliei a patra, fie a celor sinoptice, în virtutea identității cristologice dintre misiune și trimis ( Iisus este „,simpliciter” misiunea divină asumată și activată până la ascultarea extremă de pe cruce), nu este dificil să deducem continuitatea care trece de la misiunea lui Iisus la misiunea Fiului, și de la misiunea Fiului la misiunea Duhului Sfânt ${ }^{10}$. Propriu pentru faptul că Iisus este unicul care vine de sus, de la Dumnezeu, este în forma sa concret configurată (Gestalt), aceeași față a revelării lui Dumnezeu. Iisus Hristos este așa cum lui Balthasar îi place adesea să afirme împreună cu sfântul Irineu ,vederea

\footnotetext{
${ }^{7}$ Karl Barth, Church Dogmatics I. 2 The Doctrine of the Word of God, Editura T\&T Clark International Londra, 2004, p. 194.

${ }^{8}$ Hans Urs von Balthasar, Gloria. Una estetica teologica, volumul 1: La percezione della forma, 1994, p. 291; Hans Urs von Balthasar, Teodrammatica, volumul 5: L'ultimo atto, 1986, p. 48.

${ }^{9}$ Ibidem, p. 58.

${ }^{10}$ Hans Urs von Balthasar, Teodrammatica, volumul 3: Le persone del dramma: L'uomo in Cristo, 1992, pp. 475-482.
} 
invizibilului” și pentru aceasta Fiul devenit om „,rămâne summum-ul revelaţiei" ". Aceasta înseamnă mai întâi că Hristos este identitatea personală între Cel care revelează (is quo Deus revelatur) și revelaţia însăşi (id quod revelatur). Deci între omul Iisus care îl revelează pe Tatăl în puterea Duhului Sfânt si Tatăl revelat de Fiul Iisus, nu este un medium ori un tertium de revelație. Iisus Hristos este însăși revelația divină (ipsa revelatio). Pe Dumnezeu nimeni nu L-a văzut vreodată; Fiul cel Unul-Născut, Care este în sânul Tatălui, Acela L-a

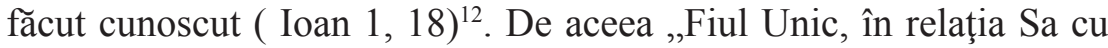
Tatăl, este în acelaşi timp cel care revelează şi cel care este revelat"13. Iisus Hristos este deasemenea totalitatea revelaţiei divine, pentru că cuvântul Său este „Alfa şi Omega”, după care Tatăl nu mai are nimic de comunicat lumii, nici în timpul actual nici în cel etern. De aceea Iisus a putut spune despre Sine: „Cel ce mă vede pe Mine, vede pe Tatăl'"(Ioan 14,9). În tot misterul Lui Iisus Hristos, de la întrupare și zămislirea virginală, la botez și până la moartea pe cruce, până la Înviere și nașterea Bisericii, același Spirit, care este „forța activă a lui Dumnezeu”, participă la această operă ,„planificată trinitar și îndeplinită împreună de Tatăl în dăruirea Fiului"'14. Pentru Balthasar la faptul Întrupării Cuvântului sunt totdeauna unite două momente și acte inconfundibil trinitare: Revelaţia și Mântuirea. Persoana divină a lui Hristos, pe cât Cuvântul S-a făcut om, devine și este ,prezența sigură a voribirii și al acţiunii lui Dumnezeu în lume, în toată puterea ascultării de Tată $1^{15}$. Într-un limbaj scolastic s-ar spune: ca urmare

${ }^{11}$ Hans Urs von Balthasar, Gloria. Una estetica teologica, volumul 1: La percezione della forma, 1994, p. 191.

${ }^{12}$ Ignace de la Potterie, Volume 1, La verite dans Saint Jean, Biblical Institute Press, 1977, pp. 211-241.

${ }^{13}$ Donatien Mollat, Saint Jean Maître Spirituel, Paris, Editura Beauchesne, 1976, p. 35-43.

${ }^{14}$ Hans Urs von Balthasar, Verita di Dio, Teologica, volumul 2, Editura Jaca Book, SpA Milano, 1990, p. 259-261.

${ }^{15}$ Hans Urs von Balthasar, Gloria. Una estetica teologica, volumul 7 Nuovo 
a Întrupării, Treimea imanentă s-a făcut Treime iconomică pentru salvarea universală. Întruparea nu este un exemplu pentru a ilustra un adevăr, este adevărul însuși, mai mult, întruparea lui Hristos este criteriul oricărui adevăr efectiv, care s-a realizat în istoria concretă a mântuiriii ${ }^{16}$. Se pune astfel întrebarea: Ce este Întruparea Cuvântului? Răspunsul speculativ cel mai vechi care a rămas aproape de nedepășit este cel al Sfântului Irineu, fondatorul ecclesiologiei: „Cuvântul lui Dumnezeu S-a făcut om și Fiul lui Dumnezeu S-a făcut Fiul Omului, pentru că omul, unit Cuvântului și primind adopția filială, deveni Fiul lui Dumnezeu. Fiul lui Dumnezeu și Domnul nostru este Cuvântul Tatălui și Fiul Omului, pentru că a fost născut ca om de Maria, care aparținea genului uman și era ea însăși creatură umană" ${ }^{17}$. Cuvântul, care este Dumnezeu, a asumat un corp din carne pentru a fi om. Pentru că este Cuvânt, şi ca şi Cuvânt a asumat carnea, El Şi-a asumat în același timp un corp constituit din concept, imagine, voce, predică" 18 . Bariera inaccesibilă a Ființei Absolute se topește ca un ghețar, și lasă să curgă din ea apele unei vitalități infinite, din care creatura se adapă si devine capabilă de a se umple de viața absolută" ${ }^{\prime 19}$. Dumnezeu trece în partea opusă a Lui Însuși, adunând în Sine păcatul, provocând deci abandonul creaturii, de către Sine Însuși, creatorul ei. Din această cauză nu încetează să fie El Însuși, ci din contră demonstrează că se află în totalitatea puterii Sale şi total în Sine. Dumnezeu poate să fie mort fără a înceta să fie viața eternă; și cu un asemenea comportament

Patto, 1991, Editura Jaca Book, SpA Milano, p. 255.

${ }^{16}$ Hans Urs von Balthasar, Verbum caro, Sezione quinta. Saggi Teologici 1. Editura Morcelliana-Jaca Book, Traducere de Giulio Colombi, Milano, 2005, p. 166.

$17 * * *$ Catechismo della Chiesa Catolica, texte originale si integrale, Varazze, Editura Libraria Vaticana, 2013, p. 303.

${ }^{18}$ Hans Urs von Balthasar, Verbum caro, Sezione quinta. Saggi Teologici 1., Traducere de Giulio Colombi, Milano, Editura Morcelliana-Jaca Book, 2005, p. 166.

${ }^{19}$ Ibidem, p.189. 
El poate demonstra definitiv că este viață și iubire, bunătate și har dezinteresat. Ne găsim în fața unui fapt absolut eshatologic.

\section{Bibliografie}

1. ***, Catechismo della Chiesa Catolica, texte originale si integrale, Varazze, Editura Libraria Vaticana, 2013.

2. Balthasar, Hans Urs von, Verita di Dio, Teologica, volumul 2, SpA Milano, Editura Jaca Book, 1990.

3. Balthasar, Hans Urs von, Gloria. Una estetica teologica, volumul 1: La percezione della forma, 1994.

4. Idem, Homo creatus est. Il linguagio di Dio, Sezione 5, Saggi Teologici 5, Volumul 24 delle Opere, Brescia, Editura Morcelliana, 1991.

5. Idem, Il cuore del mondo, Brescia, Editura Morecelliana, 1964.

6. Idem, La mia opera ed Epilogo, Einsiedeln, Editura Johannes Verlag, 1987.

7. Idem, Teodrammatica, volumul 3: Le persone del dramma: L'uomo in Cristo, 1922.

8. Idem, Teodrammatica, volumul 5: L'ultimo atto, 1986.

9. Idem, Verbum caro, Sezione quinta. Saggi Teologici 1, Traducere de Giulio Colombi, Milano, Editura Morcelliana-Jaca Book, 2005.

10. Idem, Church Dogmatics, Volumul 2, Capitolul 1, Editura T\&T Clark International, 1960.

11. Ignace de la Potterie, Volume 1, La verite dans Saint Jean, Biblical Institute Press, 1977.

12. Mollat, Donatien, Saint Jean Maître Spirituel, Paris, Editura Beauchesne, 1976.

13. Rahner, Karl, "Il Dio trino come fondamento originario e trascendente della storia della salvezza", Mysterium Salutis, Volumul 3, Queriniana, Brescia, 1969.

14. Idem, Zur Theologie der Menschwerdung, Traducere în italiană, Teologia dell Incarnazione, Saggi di cristologia e di mariologia, Roma, Editura Paoline, 1967.

15. San Giovanni della Croce, Opere, Subida del Monte Carmelo, 2 , 
capitolul 22, punctul 5, Novara, Editura UTET, 2013.

16. Speyr, Adrienne von, Johannes. Das Wort wird Fleisch. Betrachtungen über das Johannesevangelium Kapitel 1-5, Einsiedeln, Johannes Verlag, 1949.

17. Stăniloae, PreotProf. Dr. Dumitru, Teologia Dogmatică Ortodoxă, Volumul 1, Ediția a doua, București, Editura Institutului Biblic și de Misiune al Bisericii Ortodoxe Române, 1996. 